\title{
6. Federalism: a fork in the road?
}

\section{GEOFF ANDERSON AND ANDREW PARKIN}

Over its long history, the Australian Labor Party has had a complicated and sometimes inconsistent engagement with federalism (Galligan and Mardiste 1992; Parkin and Marshall 1994). The Rudd Labor government, over its truncated lifespan of less than three years, earned itself a special place in this history by embodying and projecting many elements of this complicated inconsistency.

At times, and especially in its first two years, the Rudd government, led by its prime minister, was seemingly intent on fabricating a collaborative approach that could be characterised as being in the national interest but respecting the role of the states and not especially aggrandising the role of the Commonwealth. At other times, and especially near the end, the Rudd government was more inclined to lambast the states as impediments to the national achievement of a more efficient, consistent and effective policy reform as Rudd sought a greater direct role for the Commonwealth. In some ways typical of his whole prime ministership, Kevin Rudd expressed a variety of positions at and between these polar extremities with, on each occasion, a degree of forcefulness and apparent sincerity. Thus, in the end, as in so many other respects, the Rudd approach to federalism was strangely enigmatic.

John Howard's final years as Prime Minister had seen him hone a philosophy of 'aspirational nationalism' as the rubric shaping his distinctive approach to Australia's federal system of government (Parkin and Anderson 2008). Kevin Rudd's unprecedented experience at the state level in observing and managing commonwealth-state relations as a senior adviser to the Queensland government had provided good reason for federalists to anticipate that as Prime Minister he would lead a government that might seek to reverse this centralist inheritance.

A year before becoming the leader of the Labor Party, Rudd had set out the case for cooperative federalism. While he did not subscribe to the 'mindless mantra of states' rights', he described himself as a committed federalist, believing that 'a properly functioning federation can advance the cause of progressive politics...not retard it' (Rudd 2005). Harking back to the cooperative federalism achievements under the Hawke and Keating Labor governments, Rudd suggested that a new commitment to cooperative federalism would provide 
the mechanism for the next wave of progressive policy reform. The Council of Australian Governments (COAG) - the heads-of-government forum comprising the Prime Minister, the state premiers and the territory chief ministers - was, he declared, the 'only viable model' for achieving the reform program (Rudd 2005). On winning the leadership of the Labor Party in 2006, Rudd identified enhancing federalism to be a priority. 'We can't just sit back and watch the Federation wither away', he declared (ABC 2006).

During the election campaign of 2007, commonwealth-state relations presented both an opportunity and a threat to Rudd and Labor. On the one hand, there was the opportunity to argue that only a federal Labor government could guarantee the cooperation necessary to eliminate the 'blame game' between the Commonwealth and the uniformly Labor-governed states and territories. On the other, there was the looming negative of what John Howard was to call the spectre of 'wall-to-wall Labor governments without a check or balance' (Shanahan 2007).

Less than a week after being sworn in as Prime Minister, Rudd called a meeting of state and territory leaders 'to set a new framework for co-operative commonwealth-state relations' and 'take practical steps to end the blame game' (Rudd 2007a). The stage was thus set for a possible new era in collaborative commonwealth-state relations.

Now fast forward to June 2010, five months short of the third anniversary of the triumphant 2007 election, when Kevin Rudd reluctantly stepped down as Prime Minister. The months leading up to this denouement had once again brought federalism to the fore in a pre-election atmosphere, but not this time within a context of cooperative commonwealth-state relations. Rather, the intergovernmental ambience had been soured by the fallout from Rudd's proposal-announced three months previously, on 3 March 2010 - that the Commonwealth would establish a National Health and Hospital Network, and for that purpose appropriate one-third of the GST revenues that had previously flowed exclusively to the states. The proposal severely strained fraternal ties with the Labor-governed states and saw the Liberal government of Western Australia (which had come into office under Premier Colin Barnett, in September 2008) reject Rudd's plan outright. Two months later, the Rudd government's budget announcement on 2 May of a proposed (and ultimately ill-fated) Resource Super Profits Tax (RSPT) interjected a commonwealth tax into the states' mining royalty domain and brought the resource-rich states of Queensland and Western Australia, and the aspiring resource-rich state of South Australia, into open disagreement with the Commonwealth. Across the Nullarbor, there were once again the 'rumblings of secession' (Williams 2010). 
This contrast of the impact on federalism between the beginning and the end of Rudd's term as Prime Minister is indicative of an unusual policy and political trajectory. But the picture needs to be completed by a consideration of the intervening period. The two years following the 2007 election saw the relationship between the Commonwealth and the states conducted in a less combative atmosphere than had been the case under the Howard government and, for the most part, a rhetoric of cooperation characterised public exchanges, which seemed genuine enough. Prime Minister Rudd elevated a reinvigorated COAG to a central role to drive the implementation of a challenging, ambitious policy agenda. Rudd's commitment to cooperation found tangible expression in a new financial agreement with the states that redrew the architecture of a key mechanism of commonwealth-state relations in favour of greater state autonomy, albeit overlaid with a new structure of 'national partnerships' with familiar commonwealth-controlled financial strings attached. In addition, Rudd made gestures towards a more respected and visible role for the local government sphere. The rest of this chapter details some of the key actions taken and assesses what was achieved.

A number of key issues highlight the complexities of the Rudd government's approach to federalism. Rudd's development of COAG as a central and positive institution of commonwealth-state relations contrasted with John Howard's more grudging acknowledgment of its usefulness (Anderson 2008; Parkin and Anderson 2007:32-3). A new financial arrangement granting more flexibility to the states in how they expended Specific Purpose Payments (SPPs) - long resisted during the Howard years ${ }^{1}$ - was a genuine pro-federalist innovation. This was, however, counterbalanced by a new set of highly conditional National Partnership Payments (NPPs) and by the later proposed breach of the financial agreement in terms of a GST clawback to fund public hospitals. In other key areas where effective reform requires substantial commonwealth-state cooperationhealth, education and the Murray-Darling Basin - there were both contrasts and continuity with the approach of the previous Howard government.

\section{COAG and the governance of the federation}

As a shadow minister, Rudd had described COAG as the only viable alternative to what appeared to be an increasingly dysfunctional federation (Rudd 2005). The COAG meeting that he called less than a week after being sworn in as Prime Minister confirmed COAG's intended enhanced status, with state and territory leaders joined for the first time by treasurers as full participants. In an echo of his election campaign rhetoric, Rudd announced:

1 Notwithstanding a serious Treasury-inspired proposal along these lines put forward in 1999 (Parkin and Anderson 2007:305). 
I want to use this COAG meeting to set a new framework for co-operative commonwealth-state relations and take practical steps to end the blame game. The time for buck-passing must come to an end. The time for real work to deal with real problems facing the nation must begin. (Rudd 2007a)

The Prime Minister moved quickly at that first meeting to change some key structures in the management of intergovernmental negotiations. As proposed by Rudd, COAG established a series of working parties charged with developing strategies and implementation plans. Each working party was chaired by a commonwealth minister with a senior state or territory official-not a corresponding state or territory minister-acting as their deputy. The COAG Communiqué, in a masterful piece of understatement, described this quite remarkable innovation as 'a break with previous practice' (COAG 2007). As the new Prime Minister told the media following the meeting:

We intend to turn COAG into the workhorse of the nation... We see this as part of the working machinery of the Australian nation. If you're serious about delivering national outcomes it means making sure that the states and territories and the Commonwealth are in harness together, and that's what we propose. (Rudd 2007b)

After this initial gathering in December 2007, COAG proceeded through a series of quarterly meetings. By the end of Rudd's second year in office, COAG had met nine times and, by the time Rudd had been replaced as Prime Minister, he had chaired 10 meetings. This compares with a mere two meetings in Howard's first two years as Prime Minister and the total of only 14 meetings during the 11 years of the Howard government.

The Rudd government's view of COAG as a key institution of national government was quite explicit. Addressing the 2020 Summit, the Prime Minister took credit for having 'breathed life into the once fractious COAG process'. He told Summit participants that 'governments are now working together to drive reform and achieve real outcomes for Australia' (Rudd 2008a). The Treasurer, Wayne Swan, in delivering the first budget of the Rudd government, claimed 'a reinvigorated and cooperative COAG process' as the basis for a new framework for commonwealth-state financial relations and for substantial progress on the reform agenda to enhance productivity and improve services in a wide range of areas (Swan 2008a:11-13). The Deputy Prime Minister, Julia Gillard, told her New Zealand counterparts at an Australia New Zealand Leadership Forum in June 2008 that COAG 'is becoming a dynamic part of our nation's system of government' (Gillard 2008). 


\section{Changing the financial architecture}

The Howard government - as had most previous governments at least since the 1970s - had been unapologetically adamant that commonwealth grant contributions were a legitimate vehicle for pursuing commonwealth policy and program priorities. ${ }^{2}$ As Leader of the Opposition, Rudd had received a report during the 2007 election campaign from an Advisory Group on CommonwealthState Relations ${ }^{3}$ that had recommended significant reforms in the structure and administration of SPPs (Keating et al. 2007). While Rudd indicated that he would act on those recommendations, the speed with which he subsequently acted, and the breadth of the changes that he sponsored, came as something of a surprise.

Following the first COAG meeting, Rudd announced that the Commonwealth would embark on a significant program of reform that included a radical shift in the structure and management of SPPs. His explanatory statement also demonstrated how his prior experience of the protocols of commonwealth-state relations and the structures of COAG were defining his approach to government:

Special Purpose Payments are part of the deep structure, folklore and mysticism of commonwealth-state relations. If you've worked in these areas before, as I have, they are the source of frustration at multiple levels, given the multiplicity of them and the way in which they've been designed. Now, we intend to take a different view. We want to see our SPPs rationalised in the future. (Rudd 2007b)

By the COAG meeting in Adelaide in March 2008, consensus had been reached on the key elements of this proposed new financial agreement (COAG 2008a). At the heart of the reform was a decision to radically consolidate the more than 90 SPPs into just a small number of omnibus SPPs, each permitting the states significant internal interprogram flexibility. The outcome was the creation of just five SPPs covering the key areas of health care, schools, skills and workforce development, disabilities services, and affordable housing (COAG 2008d).

For a time, it appeared that external shocks might derail the reform process. On 27 March 2008, the Prime Minister announced that Australia faced 'a global financial

2 Particularly controversial had been commonwealth-imposed grant conditions unrelated to the immediate policy or program at hand. For example, conditions for funding for infrastructure projects that insisted that state government agencies could not accept tenders and/or expressions of interest from contractors unless their agreements with unions and employees were in line with the Commonwealth's preferred position on industrial relations (Parkin and Anderson 2007:306).

3 Geoff Anderson was a member of this advisory group. The other members were Dr Michael Keating, former head of the Department of the Prime Minister and Cabinet (Chairman), Meredith Edwards, former Deputy Vice-Chancellor of the University of Canberra, and Professor George Williams, Anthony Mason Professor of Law at the University of New South Wales. 
crisis that poses very significant challenges for the global economy as well as our own' (Rudd 2008b). The government's response, however - via further attention to economic reform, enhanced competitiveness and increased productivity - appeared to have positive implications for federalism. Essential to this reform agenda, as the Treasurer explained, was 'a reinvigorated COAG process' that could 'unlock the benefits of modern federalism' so that, as partners, the Commonwealth and the states could overcome the challenges that the world economy presented (Swan 2008b). These remarks by the Treasurer followed the COAG meeting in Adelaide on $26 \mathrm{March}$, which, in retrospect, was probably the collaborative high-water mark of commonwealth-state relations under the Rudd government.

The details of the arrangements agreed in Adelaide were to be finalised at the COAG meeting planned for November 2008. As that meeting approached, the global financial crisis (GFC) that the government had described first as a challenge and then as a complication (Wanna 2009) had become a clear source of tension. Following the October meeting of COAG, media reports of a confidential brief on funding options prepared for the states suggested that they were seeking an additional \$23 billion as the price for signing up to the Prime Minister's COAG agenda (Taylor 2008). Rudd was moved to describe this as 'one of the larger try-ons of the century' (ABC 2008b).

Despite these tensions, the Intergovernmental Agreement on Federal Financial Arrangements was formally concluded at the COAG meeting in November 2008, its path smoothed by the commitment of the Commonwealth to an additional \$7.1 billion in SPP grants over the following five years (COAG 2008d). The reforms spelt out in the agreement were quite fundamental. Alongside the formal confirmation of the dramatic reduction (via consolidation) in the number of SPPs was a system of reporting against mutually agreed outcomes and performance benchmarks by an independent COAG Reform Council (CRC) in which the performance of both levels of government would be assessed.

The post-2000 GST-based system of fiscal federalism created by the Howard government, under which the states were guaranteed all of the GST proceeds, was clearly a positive development for the states by strengthening their financial, and hence policy, autonomy (Parkin and Anderson 2007:295-7). The Rudd government's SPP reforms of 2008 went a significant step further, allowing the states greatly enhanced discretion and autonomy in the utilisation of commonwealth-awarded SPP funds. The agreement to a system of financial incentives and rewards for pursuing reform - long sought by the states - also embodied a major conceptual breakthrough by attempting to shift the scrutiny of SPP-funded programs to their policy and service impact and away from the previous focus on compliance with detailed acquittal conditions that the Commonwealth had attached to its financial inputs.

There was, however, an interesting and significant counterbalancing initiative from the Commonwealth that accompanied the consolidation and freeing up of the SPPs. 
A new category of commonwealth conditional payments to the states-badged as National Partnership Programs (NPPs) - was established. The Commonwealth's intention here was to drive nationally significant reforms in areas that were unambiguously commonwealth priorities via the provision of financial rewards to the states (COAG 2008e). As a result, there are now three categories of NPPs: National Partnership Reform Payments, which aim to facilitate reforms or reward states that deliver on 'nationally significant reforms'; NPP payments, which support the delivery of specified outputs or projects; and a third category of projects that support election commitments or other specific payments that 'support national objectives and provide a financial contribution to the states to deliver specific projects' (Swan 2009:11). The constitutional authority for all of these payments remains Section 96 - the same authority that has underpinned the SPPs. The number of NPPs grew quickly, and in many ways the NPPs are becoming reminiscent of what much of the previous SPP regime used to look like.

\section{Health and hospitals}

In the 2007 election campaign, Kevin Rudd had declared an intention to end the 'blame game' in health either by agreement with the states or by a constitutional referendum to give the Commonwealth the power to impose a solution. The management of Australia's public hospitals and health system and the commonwealthstate relationships and agreements that underpinned it were thus always going to be defining issues for the Rudd government. The Prime Minister's self-imposed deadline of June 2009 as the date by which the reforms would be achieved added urgency and created a political timetable that was always going to be difficult to meet.

The first COAG meeting following the election agreed on the terms of reference for a National Health and Hospitals Reform Commission (NHHRC). This included a requirement that the NHHRC address overlap and duplication including in regulation between the Commonwealth and states.

Subsequent COAG meetings saw increases in the funding provided to the states for health. This suggested that the Prime Minister preferred to improve the performance of the states via enhancing their capacity rather than via the option of the foreshadowed alternative of a constitutional referendum battle. Meanwhile, the NHHRC was developing its plans for the nation's health and hospital system. In April 2008, it provided advice to the Commonwealth Minister for Health on a framework for the new Australian Health Care Agreement by way of a report entitled Beyond the Blame Game (NHHRC 2008a). In December 2008, the NHHRC released an interim report (NHHRC 2008b) that offered three options for systemic reform. These 
were shared responsibility with clearer accountability, the Commonwealth taking sole responsibility with delivery through regional authorities or a complete takeover by the Commonwealth (NHHRC 2008b:274).

The final report of the NHHRC was due in June 2009, coinciding with the deadline the Prime Minister had set for his announced timetable for reform or a referendum. The difficulties that announcement would create soon became apparent. One significant problem was that there had never been any clear criteria established for what would constitute successful reform sufficient to signal an end to the 'blame game'. The health agreement at COAG in November 2008 specified a number of performance measures against which the Commonwealth and the states had agreed to report to the COAG Reform Council. This process would, however, begin in the 2009-10 financial year - too distant to satisfy the politics surrounding the June 2009 deadline. Instead, in the vacuum that was created, the media focused on the release of the annual report on hospitals by the Australian Institute of Health and Welfare (AIHW), particularly the evidence that in the politically sensitive area of elective surgery waiting times had increased (ABC 2009; AIWH 2009). The Prime Minister's response that he was 'dead-set determined to get on with the business of long-term reform', that the government would 'roll up our sleeves', and his claim while he had received the NHHRC's final report that 'we need to be methodical, careful, working our way through these recommendations' (ABC 2009) served only to highlight the contrast with the 2007 commitment.

It was against this background that the Prime Minister unveiled the Commonwealth's plans for a new National Health and Hospital Network on 3 March 2010, claiming that this would be the most significant reform of the health system since the introduction of Medicare in the 1980s. The plan proposed that the Commonwealth would take the dominant funding responsibility for all public hospitals and put significantly more funding into the system. It also, however, directly challenged the role of the states because their hospital systems would instead be run by local networks. Most significantly, the Commonwealth would hold back about one-third of the GST revenues to be placed in a new National Hospital Fund to be spent only on health and hospitals (Rudd 2010). The outline of the policy came with a renewed warning to the states: if they refused to agree to the reform then a referendum would be held at the same time as the forthcoming election to give the Commonwealth all the power it needed to act (Rudd 2010).

An agreement was eventually reached at the COAG meeting held on 19 and 20 April 2010 - a meeting originally scheduled for a week earlier but delayed as prior background negotiations proved difficult. The meeting was also notable in that it was the first time a COAG meeting had stretched over two days - a further indication of the problems the proposal presented to the states, particularly the 'clawback' of GST and the implicit rupture of the Intergovernmental Agreement. 
The views of the states were put by the NSW Premier and Chair of the Council for the Federation, Kristina Keneally: 'We certainly want to protect our GST revenue from further clawback...We signed an intergovernmental agreement 18 months ago, and we see that as fundamental to maintaining the integrity of our budget' (Maher and Rout 2010). In the lead-up to the meeting, it was not altogether clear whether the Prime Minister would prevail, particularly given the strong opposition from New South Wales and the vociferous rejection of the proposal by Victorian Premier, John Brumby. Significant injections of extra funding, however, a commitment to entrenching safeguards against any further change to the GST arrangements andcrucially - a continuing role for the states as 'system managers for public hospitals' saw all of the states with the exception of Western Australia sign up to the new scheme (COAG 2010a).

Kevin Rudd called it a 'historic agreement for better health and better hospitals' (Hartcher 2010), but the Leader of the Opposition, Tony Abbott, countered that 'Mr Rudd hadn't fixed the health system and hadn't taken it over from the states' (Dodson 2010). Whatever the merits of Abbott's first observation (and at least the 'local network' basis will necessitate some significant administrative changes), Abbott was certainly right with his second point. The COAG agreement was absolutely clear that the states would remain system managers for public hospitals responsible for a range of system-wide functions and that Local Hospital Networks would be established by state governments as separate legal entities under state legislation (COAG 2010b:5).

The Liberal Premier of Western Australia held out, on the grounds that the agreement regarding the GST was one compromise too far regardless of the retained state management oversight and the generosity of the Commonwealth in committing to increases in immediate and future funding of the health system. At the traditional post-COAG media conference, he reminded the Prime Minister that the GST was barely 10 years old, that it was introduced as a substitute for other state taxes that had been either forgone or transferred to the Commonwealth, and that had been presented then as the long-term growth tax and solution to state finances. 'I am not,' he said, 'about to compromise the integrity or the importance of the GST to my state of Western Australia' (Barnett 2010).

\section{Education}

Fundamental questions about the degree to which the Rudd government wanted to influence the direction of schooling arose soon after the election. Certainly, previous commonwealth governments had utilised SPPs or direct commonwealth payments to schools in pursuit of their own policy agendas, but these had typically been directed at promoting specific pet programs. The Rudd government, in contrast, advanced a new and potentially more encompassing and more penetrating approach. 
In an address in August 2008, the Prime Minister set out three central pillars of reform in schools: improving the quality of teaching, making school reporting properly transparent and lifting achievement in disadvantaged school communities. The states and territories were 'important partners in this process', he conceded, but the Commonwealth's challenge was to get them 'to commit to concrete tangible reforms'. In an echo of the strategy also pursued by the Howard government, Rudd announced that this commitment would be gained by making agreement on individual school performance reporting a condition of the new national education agreement, and of course funding to the states (Rudd 2008c).

This marked the first time that the Prime Minister - facing a situation in which agreement was likely to be difficult - embellished the rhetoric of cooperation with a threat of fiscal coercion. As the veteran commentator Paul Kelly noted, this was not just about schools; it was also a test for Rudd of 'whether his governing model of cooperative federalism is viable' (Kelly 2008).

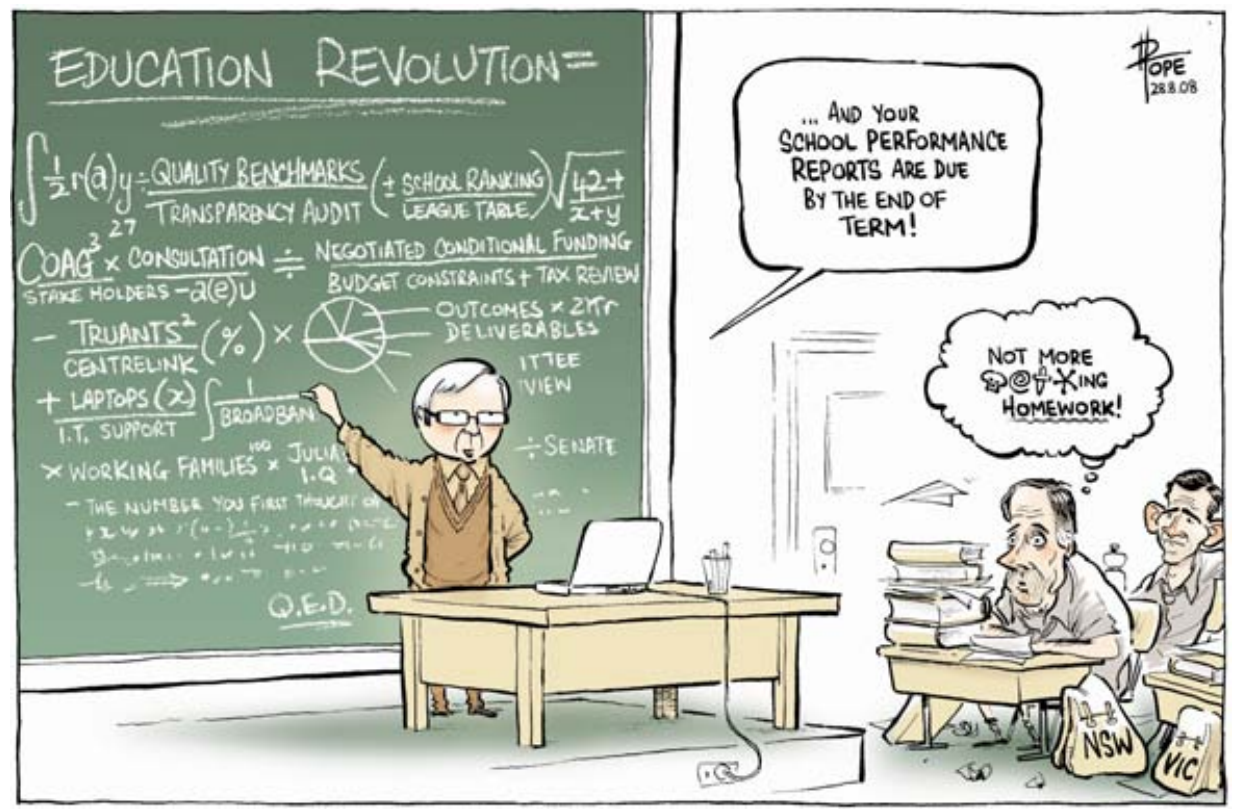

Source: David Pope, The Canberra Times, 28 August 2008

The introduction by the Commonwealth of the My School web site (ACARA 2010) was equally significant in assessing how cooperative the Rudd government would be in practice. The web site describes its purpose in terms of providing information, enabling meaningful evaluation of test results and providing opportunities to improve performance and learn from other schools (ACARA 2010). Behind this apparently innocent prose, however, is the story of a substantial and largely successful imposition by the Commonwealth- 
prominently led by Deputy Prime Minister, Julia Gillard - of a transparent national regime of student competency testing on to reluctant states and over the opposition of a hostile teachers' union. Because this approaches the heart of the actual practices and accountability of schools, this could turn out to be the most penetrating intervention yet by the Commonwealth into a policy domain otherwise unambiguously within the jurisdiction of the states. (The Rudd government's education policy is further discussed in Chapter 9 of this volume.)

\section{The Murray-Darling: still state versus state}

Negotiations over the management of the Murray-Darling Basin during the term of the Rudd government provide a stark reminder that federalism involves more than relations between the Commonwealth and the states, but also between individual states.

The cooperative federalism promoted by Kevin Rudd showed early signs of promise when at the first COAG meeting after the November 2007 election 'water reform' featured in the brief given to the working parties of commonwealth ministers and state officials (COAG 2007). This promise appeared to be moving closer to fulfilment when at the COAG meeting in March the Commonwealth and the states agreed in principle to a memorandum of understanding on reform of the management of the Murray-Darling Basin (COAG 2008a; Wong 2008). The Prime Minister called the deal 'historic' and declared an end to the 'blame game' on water (Franklin 2008). SA Premier, Mike Rann, agreed, adding that 'more has been achieved in 11-and-a-half weeks of talks over the River Murray than in the [previous] 11-and-a-half years' (ABC 2008a), while Victorian Premier, John Brumby, described it as a 'great step forward' (Wiseman 2008a).

At the next meeting of COAG, in July, it appeared that a century of federal disharmony over the basin might finally be laid to rest when the states and the Commonwealth agreed to sign an intergovernmental agreement under which the states would refer their powers to the Commonwealth and agree to the establishment of an independent Murray-Darling Basin Authority as the single body responsible for the overarching management of the basin. It appeared, however, that action to address the critical condition of the Murray would not immediately follow the agreement, because significant changes in the amount of water that could be traded across the catchment were delayed as 'COAG stated its ambition to increase the cap from four per cent to six per cent by the end of 2009' (COAG 2008b). Media commentators denounced the delay as a 'classic COAG cop out' (Steketee 2008) and it certainly appeared to be a classic stand-off between individual states. Behind this formulation in the communiqué was the determination of Premier Brumby to resist the transfer of water entitlements 
held by Victorian irrigators. He was unapologetic about this parochial stance: 'If that cap were lifted immediately, it would have a devastating effect on Victorian irrigators', he said, warning that as soon as the cap was lifted 'everyone is going to be after high security Victorian water' (Wiseman 2008b). The response of South Australia's Premier, Mike Rann, was to publicly rebuke his Labor colleague, accusing Victoria of having 'frustrated this process for the past 18 months or more' (Wiseman 2008b).

Eight months after the signing of the Murray Darling Intergovernmental Agreement, and a few weeks short of the first anniversary of the 'historic' agreement at the March 2008 COAG meeting, Premier Rann announced in the SA Parliament that having 'exhausted all diplomatic channels', his government was assembling a legal team to mount a constitutional challenge to the upstream states to protect South Australia's rights to the River Murray and 'to return sufficient permanent fresh water to the river to restore its health'. The Premier particularly highlighted Victoria's refusal to lift the cap on trading as a barrier to long-term reform (Rann 2009). The critical problem of the Murray, and in particular the impact of drought and over-allocation of water on the health of the lower lakes and The Coorong, had become a major political issue in South Australia in what was the lead-up to an election year. The court challenge, however, and the determination of Premier Brumby to protect Victorian irrigators, which brought it about, indicated the extent to which local politics can drive a state's response to 'cooperative federalism'.

\section{Local government}

The reform of the federation that Labor promoted during the 2007 election campaign focused largely on developing cooperation between the Commonwealth and the states rather than any major structural change by way of constitutional amendment. Inserting a constitutionally recognised role for local government was, however, an exception, with Rudd committing himself to pursue the process of gaining constitutional recognition for this third tier of government in Australia (Lundy 2007a). Labor also proposed to involve local governments in discussion of issues of national importance and ensure that it had a more effective voice at COAG through the creation of an Australian Council of Local Governments (ACLG) (Lundy 2007b).

In November 2008, the Prime Minister sought to make good on both these commitments when he invited the mayors of all of Australia's councils to meet with him in Canberra at what was to become the inaugural meeting of the ACLG. Addressing the meeting, he said that, in addition to creating a stronger and more coherent relationship between local government and the Commonwealth, he 
sought their input on his election commitment to its constitutional recognition. Reminding the meeting of the failure to gain bipartisan support for Labor's referenda proposals of 1974 and 1988, he said that this time he wanted to 'get it right', looking for local government to forge a consensus among councils on the nature of any change (Rudd 2008d). Later, the Commonwealth moved to assist this process with a grant of $\$ 250000$ to the Australian Local Government Association (ALGA) 'to raise the profile of constitutional recognition of local government' (AAP 2010). Similar initiatives to support the capacity of local government to play a more significant role came with the establishment of a \$25 million Local Government Reform Fund, which was focused on improving infrastructure asset management and planning (Albanese 2009a), and the contribution of $\$ 8$ million towards the establishment of the Australian Centre of Excellence for Local Government to promote best practice and encourage innovation and professionalism within the sector (Albanese 2009b).

It would be easy to dismiss these initiatives as merely symbolic. The specific role of local government in the federation was not mentioned in any communiqué from the 10 COAG meetings held during the period that Rudd was Prime Minister, and a broader examination of the roles and responsibilities of different levels of government was referred to only in regard to reports from officials on specific programs (COAG 2008c, 2008d). Two further meetings of the ACLG were held before Rudd was removed as Prime Minister; however, its large size meant that it could never become the negotiating forum represented by COAG, its meetings instead being 'conducted in the style of community cabinet meetings' with ministers and parliamentary secretaries taking questions from the floor (ACLG 2010).

Symbolism or not, the commitment and the establishment of the council were warmly welcomed by local government (ALGA 2008). Moreover, the issue of constitutional recognition became more real than symbolic for local government following the High Court's decision in Pape $v$ Commissioner of Taxation (HCA 2009). This case concerned a challenge to the constitutional validity of the cash payments made by the Rudd government as part of its GFC stimulus package. While the validity of the payments was upheld by a four-three majority, the court was unanimous that the Commonwealth may not spend in areas in which it has no constitutional authority (Saunders 2009:250). Constitutional lawyer Professor George Williams argued that the court's decision confirmed that the Commonwealth did not have any general power to regulate or fund local government and that, as a consequence, a number of programs, such as the National Building Roads to Recovery, could be invalid. He suggested an amendment to Section 96 of the Constitution that would specifically include the power to make grants to local government (Williams 2009). 
The broader implications for federalism of the decision did not receive much attention outside local government. As a former Labor Attorney-General in the Keating government commented, no 'state has grasped, or looks remotely likely to want to grasp, the potential Pape offers them to recontest the spending ground earlier claimed by the Commonwealth' (Kerr 2009:319). In many respects, the preference on the part of the Commonwealth for direct funding to local government represents a continuation of the approach of the Howard government. The point of differentiation was the willingness of the Rudd government to take the next step towards a more formal and constitutionally based relationship. While the Prime Minister reaffirmed his support for a referendum on a number of occasions, it was clearly a matter for a second term, but nonetheless a matter now firmly on the agenda.

\section{Global financial crisis}

On the eve of the November COAG meeting, the Prime Minister explained to Parliament that there was no point in 'sugar coating' what was happening, with the economies of the major developed nations 'like dominoes...falling one by one into recession' (Rudd 2008b). COAG, however, was to play its part with a 'substantial but responsible' $\$ 11$ billion to be offered to the states over four years as the third tranche of the government's plan to invest in stimulating the economy, alongside payments to pensioners and carers, families and home owners (Rudd 2008b).

Just more than two months later, COAG met again in a special meeting called to consider the Prime Minister's 'Nation Building and Jobs Plan' - the second stage of the Rudd government's economic stimulus (Rudd 2009a). Following the meeting, the Prime Minister was generous in his public praise for the states and territories for reaching agreement at such short notice (Rudd 2009b). Behind the scenes, however, he was reportedly 'obsessed' with ensuring that his plan be rolled out on time and not 'thwarted by problems with the states' (Taylor and Uren 2010:146). As a result, the National Partnership Agreement established an 'Oversight Group' within the Department of the Prime Minister and Cabinet chaired by a coordinator-general who in turn would work with coordinatorsgeneral in each state and territory. To ensure that the states did not cut back their own funding, they were to report against 'expenditure and output benchmarks' with the heads of treasuries charged with analysing these data 'to ensure that existing effort by all jurisdictions is maintained', with final oversight by the Ministerial Council for Financial Relations (COAG 2009). The pressure of the international crisis had seen commonwealth-state relations revert to more familiar territory and the COAG process slip from the heady heights of March 2008. 


\section{Conclusion}

When Kevin Rudd became Labor leader in December 2006, he declared that, after 10 years of the Howard government, Australia had reached a 'fork in the road'. He placed 'the actual fabric of our federation' at this intersection, with the choice before the country needing to go beyond 'fiddling at the margins' in the direction of 'fundamental reform' (Rudd 2006). Beyond the terrible mixed metaphors, the intention to strike out in a significantly new direction seemed clear. What eventuated?

The Rudd government began by sponsoring a significant and interesting set of reforms that made genuine progress in not only respecting the role of the states in the Australian federation but also leveraging cooperative commonwealth-state relations to achieve worthwhile reforms. But the period ended with a dispute about hospitals that, while leaving the states with continuing key healthcare delivery responsibilities, did so after a pathway that threatened to undermine key foundational elements underpinning the role of the states.

An overall perspective would allow a positive view of Rudd's contribution to Australian federalism, particularly in the further development of COAG as an institution of Australian governance. The consolidation and re-conceptualisation of SPPs formed a remarkable breakthrough. This was, however, tempered by the creation of the NPPs and the later overturning of the financial agreement on the GST. And it is also the case that even COAG - however strong the voices of the states within it - is itself an instrument of cooperative centralism that, in the end, reinforces the dominant role of the Commonwealth at least as an instigator and coordinator and frequently as a policy driver.

There has for many years been a frequent temptation for commentators to foreshadow the demise of the states as effective and autonomous actors within the federal system. Such commentary has always been premature at best and probably naive. Whatever the financial, economic and legal forces that promote centralism, the states remain powerful political entities. As one observer of the health debate commented, had the Prime Minister not made significant concessions to the states and had so many premiers not shared an overriding loyalty to the Labor Party, the premiers of New South Wales and Victoria could well have been able to force the Prime Minister into a humiliating backdown (Savva 2010). The premiers of Western Australia, Queensland and South Australia also played a significant part in the RSPT debate - a key element in Rudd's downfall from office. Many years ago, Liberal premiers were influential in the toppling of an incumbent Liberal Prime Minister, John Gorton (Hughes 1976; Nixon 2002). While not quite so visibly, the three 'mining-state' premiers probably contributed to the toppling of Kevin Rudd. 
Thus, as always, Australian federalism - a governmental construction defined via the Commonwealth-dominated legalisms of the Constitution and lubricated via the Commonwealth-dominated public finance system-can only fully be understood as, first and foremost, a realm of politics. So, likewise, the Australian Labor Party's multi-layered engagement with federalism at the Commonwealth and state levels. The politics of 2007, and the need to counter John Howard's warnings of the consequences of wall-to-wall Labor governments, brought a reformist version of cooperative federalism to the fore. The politics of 2010 found federalism still at centre stage but under very different circumstances. Politics will continue to shape the Australian federation for all of Kevin Rudd's successors, both in the prime ministership and in the Labor leadership.

Geoff Anderson is a senior lecturer in the Department of Politics and Public Policy at the Flinders University of South Australia.

Andrew Parkin is the Deputy Vice-Chancellor (Academic) and a Professor in the Department of Politics and Public Policy, Flinders University, South Australia.

\section{References}

Albanese, A. 2009a. Rudd government moves ahead with \$25 million local government reform fund, Media release, 9 October, Parliament House, Canberra, <http://www.minister.infrastructure.gov.au/aa/releases/2009/ October/aa416_2009.htm>

Albanese, A. 2009b. Centre of Excellence for Local Government officially open, Media release, 14 December, Parliament House, Canberra, <http://www. minister.infrastructure.gov.au/aa/releases/2009/December/aa538_2009. htm >

Anderson, G. 2008. 'The Council of Australian Governments: a new institution of governance for Australia's conditional federalism', The University of New South Wales Law Journal, vol. 31, no. 2, pp. 493-508.

Australian Associated Press (AAP) 2010. 'Local government given federal leg up', AAP Bulletin, 15 June.

Australian Broadcasting Corporation (ABC) 2006. 'New Labor leader outlines plan: Kerry O'Brien speaks with Kevin Rudd', Transcript, 7.30 Report, ABC TV, 4 December, <http://global.factiva.com> 
Australian Broadcasting Corporation (ABC) 2008a. 'COAG agreements on Murray-Darling system and health', Transcript, PM, ABC Radio, 26 March, <http://www.abc.net.au/pm/content/2008/s2200029.htm>

Australian Broadcasting Corporation (ABC) 2008b. 'The cost of federalism a pipe dream', Transcript, The World Today, ABC Radio, 10 October, <http://www. abc.net.au/worldtoday/content/2008/s2387704.htm>

Australian Broadcasting Corporation (ABC) 2009. 'Decide on hospital takeover: Mr Rudd's self-imposed deadline has arrived', Transcript, ABC News, 30 June, <http://global.factiva.com $>$.

Australian Council of Local Governments (ACLG) 2010. Australian Council of Local Governments meeting, Canberra, 8 June, <http://www.aclg.gov.au/>

Australian Curriculum, Assessment and Reporting Authority (ACARA) 2010. My School, Web site, Australian Curriculum, Assessment and Reporting Authority, Sydney, <http://www.myschool.edu.au/>

Australian Institute of Health and Welfare (AIHW) 2009. Australian hospital statistics 2007-08, Health Services Series No. 33, Cat. No. HSE 71, June, Australian Institute of Health and Welfare, Canberra.

Australian Local Government Association (ALGA) 2008. New Australian Council of Local Government, Media release, Australian Local Government Association, Deakin, ACT.

Barnett, C. 2010. COAG joint press conference, Transcript, Prime Minister of Australia Media Centre, Canberra, <http://pandora.nla.gov.au/ pan/79983/20100624-1429/www.pm.gov.au/node/6689.html>

Council of Australian Governments (COAG) 2007. Communiqué, Council of Australian Governments meeting, Canberra, 10 December, <http://www. coag.gov.au/coag_meeting_outcomes/2007-12-20/index.cfm>

Council of Australian Governments (COAG) 2008a. Communiqué, Council of Australian Governments meeting, Adelaide, 26 March, <http://www.coag. gov.au/coag_meeting_outcomes/2008-03-26/index.cfm\#reform_agenda>

Council of Australian Governments (COAG) 2008b. Communiqué, Council of Australian Governments meeting, Sydney, 3 July, <http://www.coag.gov.au/ coag_meeting_outcomes/2008-07-03/index.cfm\#water $>$

Council of Australian Governments (COAG) 2008c. Communiqué, Council of Australian Governments meeting, Perth, 2 October, <http://www.coag.gov. au/coag_meeting_outcomes/2008-10-02/index.cfm\#aged $>$ 
Council of Australian Governments (COAG) 2008d. Communiqué, Council of Australian Governments meeting, Canberra, 29 November, <http://www. coag.gov.au/coag_meeting_outcomes/2008-11-29/index.cfm\#reform>

Council of Australian Governments (COAG) 2008e. Intergovernmental Agreement on Federal Financial Relations, December 2008, Council of Australian Governments, Canberra, <http://www.coag.gov.au/intergov_agreements/ federal_financial_relations/index.cfm $>$

Council of Australian Governments (COAG) 2009. Communiqué, Nation Building and Jobs Plan, Special Council of Australian Governments meeting, 5 February 2009, <http://www.coag.gov.au/coag_meeting_outcomes/2009-02-05/index. $\mathrm{cfm}>$

Council of Australian Governments (COAG) 2010a. Communiqué, Council of Australian Governments meeting, 19-20 April, <http://www.coag.gov. au/coag_meeting_outcomes/2010-04-19/index.cfm?CFID=465751\&CFTOK $\mathrm{EN}=81186534>$

Council of Australian Governments (COAG) 2010b. National Health and Hospitals Network Agreement, Council of Australian Governments, Canberra, <http:// www.coag.gov.au/coag_meeting_outcomes/2010-04-19/index.cfm?CFID=46 5751\&CFTOKEN $=81186534 \#$ reforms $>$

Dodson, L. 2010. 'Rudd faces Senate row on health', Australian Financial Review, 22 April.

Franklin, M. 2008. 'Rudd delivers on new federalism', The Australian, 27 March, p. 1.

Galligan, B. and Mardiste, D. 1992. 'Labor's reconciliation with federalism', Australian Journal of Political Science, vol. 27 (special issue), pp. 71-86.

Gillard, J. 2008. Priorities for the new Australian government, Speech at the Australian and New Zealand Leadership Forum, 13 June, <http://www. pm.gov.au/node/5740>

Hartcher, P. 2010. 'Confident PM sets the stage for election', Sydney Morning Herald, 21 April.

High Court of Australia (HCA) 2009. Pape v Federal Commissioner of Taxation (2009) 257 ALR 1, 83 ALJR 765.

Hughes, C. A. 1976. Mr Prime Minister. Australian Prime Ministers 1901-1972, Oxford University Press, Melbourne.

Keating, M., Anderson, G., Edwards, M. and Williams, G. 2007. A framework to guide future development of Specific Purpose Payments, Discussion Paper by the ALP Advisory Group on Federal State Relations, July, Sydney. 
Kelly, P. 2008. 'The PM's courageous gamble', The Australian, 30 August, p. 21.

Kerr, D. 2009. 'Pape $v$ Commissioner of Taxation: fresh fields for federalism?', Law and Justice Journal, vol. 9, no. 2, pp. 311-23.

Lundy, K. 2007a. Labor to drive constitutional recognition of local government, Media release, 27 August, Parliament House, Canberra, <http://pandora.nla. gov.au/pan/22093/20071022-1405/www.alp.org.au/media/0807/mslg270. html>

Lundy, K. 2007b. Labor to establish Council of Australian Local Governments, Media release, 29 August, Parliament House, Canberra, <http://pandora.nla. gov.au/pan/22093/20071022-1405/www.alp.org.au/media/0807/msfsrlg290. html>

Maher, S. and Rout, M. 2010. 'Hospital talks deadlocked over GST-Rudd stares down states on health', The Australian, 19 April, p. 1.

National Health and Hospitals Reform Commission (NHHRC) 2008a. Beyond the Blame Game: Accountability and performance benchmarks for the next Australian Health Care Agreements, National Health and Hospitals Reform Commission, Woden, ACT, <http://www.health.gov.au/internet/nhhrc/ publishing.nsf/Content/commission-1lp>

National Health and Hospitals Reform Commission (NHHRC) 2008b. A Healthier Future for all Australians Interim Report, December, National Health and Hospitals Reform Commission, Woden, ACT, <http://www.health.gov.au/ internet/nhhrc/publishing.nsf/Content/interim-report-december-2008>

Nixon, P. 2002. 'A man for the good of his nation - a Prime Minister's life', The Australian, 21 May, p. 11.

Parkin, A. and Anderson, G. 2007. 'The Howard government, regulatory federalism and the transformation of commonwealth-state relations', Australian Journal of Political Science, vol. 42, pp. 295-6.

Parkin, A. and Anderson, G. 2008. 'Reconfiguring the federation?', in C. Aulich and R. Wettenhall (eds), Howard's Fourth Government: Australian Commonwealth Administration 2004-2007, UNSW Press, Sydney, pp. 93113.

Parkin, A. and Marshall, V. 1994. 'Frustrated, reconciled or divided? The Australian Labor Party and federalism', Australian Journal of Political Science, vol. 29, no. 1, pp. 18-39.

Rann, M. 2009. Ministerial statement, House of Assembly Hansard, 5 March 2009, p. 1881. 
Rudd, K. 2005. The case for cooperative federalism, Address to the Don Dunstan Foundation, Queensland Chapter, 14 July, <http:/www.dunstan.org.au/ resources/lectures.html>

Rudd, K. 2006. New Labor leadership team, Transcript, Press conference, 4 December, Parliament House, Canberra, <http://pandora.nla.gov.au/ pan/22093/20061206-0000/www.alp.org.au/media/1206/pcloo040.htm>

Rudd, K. 2007a. Meeting of the Council of Australian Governments, effective federalism for the future: practical steps towards ending the blame game and boosting productivity growth, Media release, 10 December, Parliament House, Canberra, <http://www.pm.gov.au>

Rudd, K. 2007b. Joint press conference with Premiers Brumby, Iemma, Bligh, Carpenter, Lennon, Acting Premier Foley, and Chief Ministers Stanhope and Henderson, following the Council of Australian Governments meeting, Transcript, Government House, Melbourne, <http://www.pm.gov.au/ node/6000>

Rudd, K. 2008a. Preparing Australia for global competitiveness in the 21st century, Address to the 2008 Future Summit, 11 May, <http://www.pm.gov. au/node/5803>

Rudd, K. 2008b. House of Representatives, Debates, 27 November, p. 11721.

Rudd, K. 2008c. Quality education: the case for an education revolution in our schools, Address to the National Press Club, Canberra, 27 August, <http:// pandora.nla.gov.au/pan/79983/20081112-0133/www.pm.gov.au/media/ Speech/2008/speech_0443.html>

Rudd, K. 2008d. Address at the Australian Council of Local Government meeting, <http://www.aclg.gov.au/media_centre/speeches2008.aspx>

Rudd, K. 2009a. Prime Minister's address to the nation, Transcript, Parliament House, Canberra, 3 February, <http://pandora.nla.gov. au/pan/79983/20090212-0444/www.pm.gov.au/media/Speech/2009/ speech_0786.html>

Rudd, K. 2009b. Joint press conference of COAG meeting, Transcript, Main Committee Room, Parliament House, Canberra, 9 February, <http:// pandora.nla.gov.au/pan/79983/20090212-0444/www.pm.gov.au/media/ Interview/2009/interview_0795.html>

Rudd, K. 2010. Better health, better hospitals: the national health and hospitals network, Speech to the National Press Club, Canberra, 3 March, <http:// pandora.nla.gov.au/pan/79983/20100624-1429/www.pm.gov.au/node/6534. html> 
Saunders, C. 2009. 'The sources and scope of Commonwealth power to spend', Public Law Review, vol. 20, no. 4 (December), pp. 256-63.

Savva, N. 2010. 'Rudd revenge on ALP agenda', The Australian, 27 April, p. 10.

Shanahan, D. 2007. 'Politically correct will stay in the doghouse', The Australian, 23 November.

Steketee, M. 2008. 'Deferred decision a classic cop out', The Australian, 4 July, p. 5.

Swan, W. 2008a. Australian federal relations, Budget Paper No. 3, Commonwealth of Australia Budget 2008-09, Commonwealth of Australia, Canberra, <www. budget.gov.au>

Swan, W. 2008b. House of Representatives, Debates, 27 November, p. 11729.

Swan, W. 2009. Australian federal relations, Budget Paper No. 3, Commonwealth of Australia Budget 2009-10, Commonwealth of Australia, Canberra, <www. budget.gov.au>

Taylor, L. 2008. 'States demand $\$ 23$ bn as price of backing Rudd reform', The Australian, 10 October, p. 1.

Taylor, L. and Uren, D. 2010. Shitstorm, Melbourne University Press, Carlton, Vic.

Wanna, J. 2009. 'Political chronicles, Commonwealth of Australia July to December 2008', Australian Journal of Politics and History, vol. 55, no. 2, pp. 261-315.

Williams, G. 2009. Advice to the Australian Local Government Association: Re: Pape $v$ Commissioner of Taxation and direct funding of local government, 12 August, <http://www.councilreferendum.com.au/>

Williams, G. 2010. 'Too rich, too weak to succeed seceding', The Age, 11 May.

Wiseman, J. 2008a. 'History making deal shares rivers-Rudd's new federalism', The Australian, 27 March, p. 4.

Wiseman, J. 2008b. 'Premier's spray taps Murray frustration', The Australian, 5 July, p. 2.

Wong, P. 2008. Murray Darling deal delivered, Media release, 26 March, Parliament House, Canberra, <http://www.climatechange.gov.au/ /media/ Files/minister/wong/2008/Media\%20Releases/March/mr20080326.ashx> 